\title{
Tales of Viziers and Wine: Interpreting Early Ottoman Narratives of State Centralization
}

\author{
Dimitri Kastritsis
}

The dominant paradigm of Ottoman state-building is one of progressive centralization and institutionalization, from the late fourteenth to the midsixteenth century CE. This paradigm was first developed by Paul Wittek in the 1930s, and later refined by Halil Inalcık and others. ${ }^{1}$ According to Wittek's wellknown thesis, the Ottoman state-building venture was at first an egalitarian affair. Frontiersmen with a more or less tribal and nomadic background, possessing a deep religious devotion embodied by holy men, carried out religiously motivated raids $(\dot{g} a z \bar{a})$ into Christian territory. By means of such activity, they were able to push the frontiers of Islam from the Anatolian borders of Byzantium to the Danube and Adriatic. But as the borders of their principality grew and its frontier advanced into Europe, a hinterland developed, in which the need for central state institutions became apparent. Such institutions were modelled on those already present in other Islamic states. They included shari'a courts, taxation based on population surveys, and employment of slaves in the army and state administration. Since at first the Ottoman principality consisted of territory newly conquered for Islam, in order to build such institutions, there was a need for scholars (ulema, Ar. 'ulamä') imported from outside the Ottoman borders. Members of this new class (distinct from the holy men already mentioned) entered the Ottoman domains from rival Muslim principalities to the east. At first they mainly came from the neighboring Turkish emirates (beyliks) of Anatolia. Some of these emirates enjoyed considerable prestige in the region, and their competitive relationship with the Ottomans meant that people coming from them were viewed with suspicion.

According to the Wittek paradigm, such negative perceptions were rooted in more than just political rivalry, but could ultimately be traced to cultural differences. For to the original founders of the Ottoman state (the $\dot{g} \bar{a} z \bar{\imath}$ frontiersmen),

1 Wittek, The Rise of the Ottoman Empire. On Wittek's ideas, see especially Kafadar, Between Two Worlds; Wittek, ed. Heywood, The Rise of the Ottoman Empire. Publications reflecting the later formulation include İnalcık "Ottoman Methods of Conquest”; Inalcık, The Ottoman Empire; Shaw, History of the Ottoman Empire, vol. 1. 
the newcomers were so different that they were perceived as threatening a former way of life. However, despite initial $\dot{g} \bar{a} z \bar{\imath}$ resistance, after the conquest of Constantinople (1453), it became more difficult to question the nature of the empire and its institutions, many of which had been created by the aforementioned scholars. So the disenfranchised frontiersmen were forced to take out their frustrations in the field of literature. How else to explain the fact that histories compiled in the late fifteenth century include colorful stories, in which scholars and bureaucrats are vilified as the root of all evil in Ottoman society? In these accounts, the villains par excellence are the Çandarlı family of viziers, whose members dominated Ottoman central administration in the century preceding the conquest of Constantinople. Unlike later magnates, who were mostly of slave origin $(\mathrm{kul})$, the Çandarlı were members of the ulema. But they were also known for their diplomatic skills. Their last prominent member, Çandarlı Halil Paşa, was executed following the conquest of Constantinople, because he had favored a more flexible approach toward the Christian world. After this event, the entire family was disgraced, hence their vilification in the aforementioned texts. Or so the story goes.

It is not my purpose here to call into question the basic contours of the above paradigm, which however reductionist at times is not without its merits. In many respects, the scholarly debate over Wittek's ideas has generated more heat than light over the past few decades, and it would be counterproductive to engage in any further polemics. Thanks to the work of Cemal Kafadar, Colin Heywood, and others, it is now mostly clear what is of value about Wittek's theory and where the main problems lie. ${ }^{2}$ What is still largely absent, however, is a clear, detailed understanding of the historical evolution of Ottoman government and society in the century preceding 1453 . Both Wittek's and Kafadar's books are essentially extended essays, while Heywood's work has focused on the intellectual underpinnings of Wittek's ideas more than on early Ottoman history per se. Moreover, the focus of these works has been largely on the period of Ottoman history that is the most difficult to understandnamely, the reigns of the first three Ottoman rulers (Osman, Orhan, and Mu$\operatorname{rad} \mathrm{I}, 1299-1389$ ). This was a time when the Ottoman principality was not a major power, so sources are few and far between. But in fact, far more can be done with the following century: the period that witnessed the first Ottoman attempt at empire, its collapse, its reconstruction, and its definitive establishment

2 For analysis and bibliography, see the above cited works by Kafadar and Heywood. See also Lowry, The Nature of the Early Ottoman State. Yürekli, Architecture and Hagiography, 65-78 also contains a useful discussion of the role of $\dot{g} \bar{a} z \bar{\iota}$ elements in the production of alternative narratives of Ottoman state formation. 
under Mehmed II (1389-1481). ${ }^{3}$ There is no recent monograph on this period as a whole, and despite the pioneering work of Halil İnalcık and others, ${ }^{4}$ our understanding of the Ottoman state, culture and institutions is still much poorer than that of the sixteenth-century 'classical age'.

The present contribution is of limited scope. Its aim is to demonstrate that there is much to be gained from considering Ottoman narratives of the central state and its actors intertextually, as well as in light of the specific historical context, however unclear this may sometimes be. In order for such study to be possible, it is necessary to move beyond the familiar boundaries of language and genre. As we will see, careful consideration of the various stories about the Çandarlı and other elite actors, which survive not only in Turkish, but also in other languages, reveals that these tales are more widespread and complex than has thusfar been appreciated. Far from mere fabrications with obvious moral and political agendas, the tales have their own history, which in many cases spans a century or more. Not infrequently, they were originally rooted in actual events and situations, which may sometimes be traced even through archival records. Nevertheless, the relationship between historical reality and representation is still far from straightforward. Stories were altered through oral and textual transmission and adapted to suit changing political agendas, as well as the needs of different genres and audiences. However, by viewing them in the appropriate historical and literary context, it is often possible to gain a more nuanced understanding of the social tensions brought about by the Ottoman state-building enterprise.

When discussing the rise of a discourse opposed to state centralization and its protagonists, historians have pointed to the key role played by the disaster of 1402, in which Timur dismembered the first Ottoman attempt at empire and

3 On this point, see Darling, "Introduction: Ottoman Identity", 53. Franz Babinger's monograph on Mehmed II (Babinger, Mehmed the Conqueror) is dated, and there is still no extensive study of the reigns of Murad I and Bayezid I, the period that witnessed the first Ottoman attempt at empire. Murphey, "Bayezid I's Foreign Policy Plans and Priorities" is a step in the right direction, but is only a chapter in an edited volume. My own Sons of Bayezid shows what can be done with a single decade by carefully interpreting a variety of available documentary and narrative sources in different languages.

4 See especially İnalcık, Fatih Devri Üzerinde Tetkikler ve Vesikalar; Imber, The Ottoman Empire 1300-1481. 
left the Ottomans in a state of civil war. ${ }^{5}$ As we will see below, it is indeed the case that sources datable to the immediate aftermath of the event in question already contain stories about the Çandarl family, which had by that time already produced two powerful viziers, Kara Halil and Ali Paşa (d. 1406). The presence of such stories should come as no surprise, for there is every indication that Ottoman attempts to create a centralized empire before 1402, a process in which the Çandarlı had been intimately involved, had been highly controversial. It is only natural that the failure of these efforts would have vindicated those opposed to them all along. More surprising, however, is that some of the key elements of the discourse of opposition can be traced to one of the Ottoman princely courts of the time, that of Mehmed I, who reigned in parts of Anatolia from 1402-13, then as single Ottoman ruler until 1421. This curious fact, which will be discussed in detail in the coming pages, suggests that the discourse in question was intimately connected to political struggles at the highest levels of government. The implication is a political and social situation more complex than has so far been recognized. Of course, accepting these court connections does not disprove Wittek's contention that discontented $\dot{g} \bar{a} z \bar{\imath}$ frontiersmen are ultimately behind such perspectives. But at the very least, it complicates the story; for as we will see, it suggests that widespread anti-Çandarlı sentiment ( $\dot{g} \bar{a} z \bar{\imath}$ or otherwise) was manipulated for political gain. Moreover, although the tensions present at the turn of the fifteenth century were not resolved in earnest until the end of that century, when the vilification of the Çandarlı received its final formulation, earlier in the century the political situation was apparently more fluid, and so was the discourse. Indeed, it is this very fluidity that permitted such narratives to be deployed by such a wide range of groups and individuals, even including the court of an Ottoman prince.

In the pages that follow, I will focus largely on the negative presentation of the Çandarlı viziers in narrative sources, and the interpretive gaps that arise when this is understood simply by reference to the Wittek paradigm. But before proceeding, it is necessary to introduce the reader to the problem and its history. In modern historical scholarship, the vilification of the Çandarlı in early Ottoman literature has been evident for at least a century. It first attracted the attention of scholars with Friedrich Giese's publication in 1922 of a corpus of historical texts from the fifteenth century, which have come to be known as the Anonymous Chronicles of the House of Osman (Tevārīh-i Āl-i 'Oșān,

5 See especially Kafadar, Between Two Worlds, 93-95. 
hereafter Anonymous Chronicles). ${ }^{6}$ Among its many strands, this corpus contains such passages as the following:

At that time [the reign of Murād I (1362-89)] ... the rulers [pādishāh] were not greedy. Whatever came into their hands they gave away again, and they did not know what a treasury was. But when [Çandarlı] Hayreddin Pasha came to the Gate [of government] greedy scholars became the companions of the rulers. They began by displaying piety and then went on to issue rulings. "He who is a ruler must have a treasury", they said ... Whatever oppression and corruption there is in this country is due to scholars. ... [They] commit adultery and pederasty, lend money on interest, and make no difference between permitted and forbidden. ... Until Vulkoglu's daughter came to him, Ylldırım Khan did not know what drinking parties were. He did not drink and held no carouses. In the times of Osmān, Orkhān Ghāzi, and Murād, wine was not drunk. At that time there were ulema who made their words effective. At that time the Sultans were ashamed before the ulema.... When the Persians and the Karamanlis became the companions of the princes of the house of Osmān, these princes commited all kinds of sins.... Until then nothing was known of keeping account books. The practice of accumulating money and storing it in a treasury comes from them. ... When [Çandarlı] 'Alī Pasha ... became vizier, sin and wickedness increased. ... The house of Osmān was a sturdy people, but these outsiders came to them and introduced all kinds of tricks. ${ }^{7}$

The above summary was compiled by Cemal Kafadar, who has spoken of an "exceptionally poignant line of criticism" against schoolmen (dānışmends) and other educated people (ulema) who came to the Ottoman domains from cultural centers further east. ${ }^{8}$ Like others before him, Kafadar has traced such views to frontier elements opposed to state centralization, while at the same time complicating the picture by considering a wider cultural setting in which this discourse should be understood. Despite the undoubtable value of such contextualization, however, what is still largely absent is a detailed understanding of

6 Anonymous, ed. Giese, Die altosmanischen anonymen Chroniken. For some basic information on this source, see Kastritsis, "Ottoman Anonymous Chronicles". See also Kafadar, Between Two Worlds, 96, 102-116.

7 Kafadar, Between Two Worlds, 111. Original translations from Lewis, Islam from the Prophet Muhammad, vol. 1, 135-141.

8 Kafadar, Between Two Worlds, 110. 
the full scope of these views, as well as the specific historical context in which they evolved.

Before turning to some examples of what such a broader approach may offer, a few more words are in order about the history of the existing interpretation. Just seven years after the publication of Giese's edition of the Anonymous Chronicles, Wittek collaborated with Franz Taeschner on an important article which presented the careers and major monuments of the Çandarlı family's principle members. ${ }^{9}$ Although this work is still useful today, as one might expect for a historical study dating to the 1920s, it is mostly a positivist exercise with little to say about the wider questions that concern us here. To the extent that the Anonymous Chronicles are mentioned at all, they are treated mainly as a source of more or less reliable historical data. The hostile attitudes present in these texts are mentioned in passing, then quickly dismissed as a predictable reaction against unpopular reforms and the rising power of the ulema. ${ }^{10}$

In fact, Wittek would make his position clearer in two subsequent publications. ${ }^{11}$ The first was The Rise of the Ottoman Empire (1938), a slim book for which Wittek is mostly remembered today, in which somewhat surprisingly the Çandarlı are not even mentioned. However, Wittek devoted a lengthy passage to them in the second, a less known article in French published around the same time. It is worth quoting from this in detail:

We shall later see further proof that the representatives of the ghâzî and Muslim tendencies found themselves set one against another in more or less open opposition. [...] The cooperation of the two tendencies was not guaranteed by any superimposed institution, but was achieved rather by the personal cooperation of their representatives. Thus we see Murâd I, at the end of his reign, putting both [the marcher lord] Evrenos Bey and the theologian vizier Khaireddîn Pasha in charge of the conquest of Macedonia. This vizier, Khaireddîn Çandarl, is the ancestor of a family for whom the position of vizier was hereditary throughout our period of study. Their place at the head of the administration brought the Çandarlı great wealth. Their economic interests led them to Byzantine

9 Anonymous, ed. Giese, Die altosmanischen anonymen Chroniken; Taeschner and Wittek, "Die Vezirfamilie der Ğandarlyzāde".

$10 \quad$ Taeschner and Wittek, "Die Vezirfamilie der Ğandarlyzāde", 69, 79.

11 Wittek, The Rise of the Ottoman Empire; Wittek, 'De la défaite d'Ankara'. Both pieces originated as public lectures: the first in London, the second in Paris. They were recently republished in English along with other material and an introduction by Colin Heywood (Wittek, ed. Heywood, The Rise of the Ottoman Empire). This book makes it possible to follow the evolution of Wittek's thought over time. 
Constantinople-still the commercial centre for the whole of the Levant. [...] The Çandarlı were the Ottoman state's first 'ministers of foreign affairs'. [...] 'Alî Pasha and Ibrâhîm Pasha, Khaireddîn's sons, are presented in the sources as prudent counsellors who endeavoured to lead Bâyezîd [I, 1389-1402] toward a policy of caution and moderation. But it would not be until the next generation that these early Ottoman diplomats would acquire enough experience to serve the state with a foreign policy that was no longer exclusively based on force[...]

As regards domestic policy, the Çandarlıs' position was determined by the fact that they belonged to the class of the 'ulemâ: they are explicitly described as such in the sources. This, and their wealth, and their relations with the foreign world, suffice to explain why the chroniclers, ghâzî spokesmen in the main, are not very favourable towards them. ${ }^{12}$

The above discussion is striking both for its emphasis on the Çandarlı's influence in diplomacy and foreign affairs, and for its superficial treatment of their role in matters of internal administration. To the extent that this role is mentioned at all, it is reduced to the fact that the Çandarlı were members of the ulema. We might expect as much, for such a perspective is perfectly in keeping with Wittek's theory of a dichotomy between the raiders and religious classes in the early Ottoman polity.

For Wittek's successors, however, it was precisely the Çandarlı family's role in internal reforms that was most worthy of attention. Writing at a time when the Annales school of historiography was highly influential in Ottoman studies, Halil İnalcık drew attention primarily to internal social dynamics, specifically the conflict between centralizing and centrifugal elements in the early Ottoman polity. ${ }^{13}$ İnalckk and others following in Wittek's footsteps understood that it was impossible to accept at face value his simple division between frontiersmen and ulema. For them, the negative presentation of the Çandarlı was to be understood as a reaction of pre-existing elites ( $\dot{g} \bar{a} z \bar{\iota}$ or otherwise) against progressive Ottoman centralization and institutionalization. According to this theory, after the Çandarlı and other learned outsiders introduced such institutions as Islamic courts, taxation, and bookkeeping, they were blamed for corrupting a supposedly 'pure' social order embodied by frontiersmen and sufi

12 Wittek, 'De la défaite d'Ankara', 12-13; English translation in Wittek, ed. Heywood, The Rise of the Ottoman Empire, 144-145.

13 For the period in question, see İnalcık, The Ottoman Empire, 10-14, 65; İnalcık, "Ottoman Methods of Conquest". For the broader emphasis on social history in Ottoman studies, see İnalcık, An Economic and Social History; İnalck, "Impact of the Annales School"; İnalcık, "Centralization and Decentralization"; Barkey, Bandits and Bureaucrats. 
mystics (the various dervish şeyhs and babas). When the central state and its institutions became firmly established under Mehmed II, the previous elites found themselves dispossessed, and took out their frustration by writing their own version of Ottoman history. The Çandarlı became its villains. They were an easy target, since they were no longer in favor after 1453.

\section{2 Çandarlı Kara Halil and the early Ottoman state}

Whatever the merits of such a view, there can be little doubt that in order to properly address the question, it is necessary to consider in more detail the careers of individual members of the Çandarlı family. The following is a brief survey of what is known of the dynasty's founder, Çandarlı Kara Halil. It should be stated outright that the state of our knowledge on the entire family consists of a small book by İ.H. Uzunçarşll, which is in fact little more than an extended encyclopedia article. ${ }^{14}$ There are no other biographies or individual studies, despite the fact that three of the Çandarlı viziers were among the most important statesmen in Islamic history. In fact, even basic facts about the family are still unclear or completely unknown. For example, although it seems obvious that the Çandarlı derived their name from their place of origin, this place is far from easy to trace. The most likely candidate is a small town in the district of Sivrihisar. ${ }^{15}$ This was presumably the original home of the family's founding father, a man called Halil or Kara Halil, who became known as Hayreddin Paşa after he became vizier around 1365 . Little is known about his background, scholarly or otherwise, apart from the fact that he came into Ottoman territory from further east. While Uzunçarşlı speculates about his education, he also admits that there is little to go on before Kara Halil's appointment as qadi. ${ }^{16}$ Although Halil was supposedly a member of the ulema, this needs to be qualified; in fact, he appears to have been educated not in the madrasa, but rather in sufi circles. He was apparently a disciple of a certain Şeyh Fahreddin, and may have been connected to Şeyh Edebali, the holy man whose daughter the first Ottoman ruler Osman Gazi allegedly married. ${ }^{17}$

Although the few available sources present Kara Halil as a recent arrival from further east, apparently his career under the Ottomans had begun as early

14 Uzunçarşıll, Çandarlı Vezir Ailesi. The author is himself a descendant of the family in question, as is clear from the genealogical appendix.

15 Uzunçarşıll, Çandarlı Vezir Ailesi, 1-2.

16 Uzunçarşılı, Çandarlı Vezir Ailesi, 3.

17 Uzunçarşıll, Çandarlı Vezir Ailesi, $3-5$. 
as the reign of the dynasty's founder, Osman Gazi (d. 1324?) By the standards of the time, he was sufficiently educated to qualify as an Islamic judge, for under Osman he became qadi of Bilecik, a small western Anatolian city that was an important Ottoman center. During the reign of Osman's successor Orhan (d. 1362), he was promoted to the post of qadi of İznik (Nicaea), a major former Byzantine town which had fallen to the Ottomans in 1331. A few years later, he was made qadi of Bursa, the recently conquered Ottoman capital. But this last promotion was not immediate, only taking place in 1348 , when the previous incumbent left the post to become vizier. ${ }^{18}$ At this time in Ottoman history, the vizierate was still a post of a purely consultative and administrative nature, rather than one with a military dimension. This might help explain why it was given to a man of learning rather than a general. As for the qadiship of Bursa, in 1348 it was the top position in the Ottoman learned hierarchy. But this would change around 1362 , when the post of $q \bar{a} d \bar{l}-$ 'askar (head military judge) was created for Kara Halil. ${ }^{19}$ Eventually, he would attain the vizierate, probably ca. 1365, during the reign of Murad I (r. 1362-89). Kara Halil Çandarlı is considered the first grand vizier, because in his person the roles of vizier and general (beylerbeyi) were combined for the first time.

Based on the above, it is possible to say that the career of Kara Halil closely followed the evolution of the Ottoman polity, from a minor principality to the main power-broker in Anatolia and the Balkans. The creation of new posts can be explained by the practical necessities of territorial expansion, but also in more political and international terms, as the result of an Ottoman need to compete for prestige with other local and regional powers. For example, it is probably no coincidence that the newly created Ottoman post of $q \bar{a} \bar{a}_{\bar{l}}$-'askar already existed among the Mamluks. As they became the main power in Anatolia, the Ottomans began to compete with this major rival on their southern border, an established state that enjoyed the prestigious title of guardian of the holy shrines of Mecca and Medina (khädim al-haramayn). ${ }^{20}$ All of this goes some way toward explaining how the Çandarlı family came to be so dominant in Ottoman administration. For it seems that already in the person of its founder Kara Halil, the family was making itself indispensable to the Ottoman rulers through a combination of scholarly, administrative, diplomatic, and even military skills. These roles were eventually separated, once the Ottoman ruling apparatus had reached a more structured and specialized state of development. After the conquest of Constantinople in 1453, following a trend that had begun already under Mehmed I and Murad II, slaves of the Porte ( $k u l)$

\footnotetext{
18 Uzunçarşılı, Çandarlı Vezir Ailesi, 6. This man was Kayserili Sinaneddin Yusuf.

19 Uzunçarşılı, Çandarlı Vezir Ailesi, 6-7.

20 Uzunçarşılı, Çandarlı Vezir Ailesi, 7.
} 
came to dominate Ottoman administration, and it was no longer considered appropriate to appoint viziers from among the ulema. ${ }^{21}$

After these observations, we may return to the career of Kara Halil Çandarlı and his descendants. It is worth noting that after assuming the post of grand vizier, Kara Halil changed his name to the more Islamic Hayreddin (Hayr al-Din). In his foundation documents and building inscriptions, he appears with the even loftier name Hayr al-Mille ve 'd-Dìn. In fact, such practices follow parallel developments in the titulature of Ottoman sultans. ${ }^{22}$ As for Kara Halil's military role, its importance has been known since the early work of Taeschner and Wittek..$^{23} \mathrm{He}$ was one of the protagonists of the conquest of Rumelia, the all-important European part of the Ottoman conquests, where he worked alongside the great marcher lord Hacı Evrenos on the east-west axis of the ancient Via Egnatia. There is little doubt that the new Ottoman conquests held a central place in Halil's career. According to Uzunçarşıll, Halil was made vizier in Gallipoli, at a time when Murad I was leaving Rumelia to pursue other activities in Anatolia following the conquest of Adrianople (Edirne). That would explain why one of the three mosques built by Kara Halil was in Gallipoli. The other two were in İznik and Serres (Siroz), towns that also marked significant stages in his career. ${ }^{24}$

To sum up, Kara Halil performed crucial services for the early Ottoman rulers, services that ranged from the judicial to the administrative, from the diplomatic to the military. He built major infrastructure in the form of mosques, and was one of the key protagonists of the conquest of new Ottoman territory in the southern Balkans. For his image in the Anonymous Chronicles, however, what is most crucial is his role in initiating administrative and military reform. Among the institutions for which he is credited (or more accurately, blamed) are the famous janissary corps and the yaya, a Turcoman infantry corps attached to the janissaries. Moreover, if we are to trust the Anonymous Chronicles, he was also behind the creation of a central treasury and taxation making

21 İnalcık, An Economic and Social History, 13. It is worth noting that Mehmed I's grand vizier Bayezid Paşa, the key figure behind his administration, was probably also a slave of the Porte. See Kastritsis, "Bayezid Paşa”.

22 In the Ottoman ruler Orhan's endowment deed dated 1324, both Orhan and his father Osman are mentioned with similar Islamic epithets. See Kafadar, Between Two Worlds, 61, 168 n. 4 .

23 Taeschner and Wittek, "Die Vezirfamilie der Ǧandarlyzāde", 71-76.

24 The mosque in Gallipoli does not survive. For the one in İznik, see Ayverdi, Osmanli Mi'mârîsinin İlk Devri, 309-319. For the one in Serres, which was destroyed in the fire of 1913, see Balta, "Les vakifs de Serrès", 91-93. See also Taeschner and Wittek, "Die Vezirfamilie der Ğandarlyzāde", 62-65, 77-78. 
use of account books (defter). In short, he was responsible for Ottoman central administration as we know it.

\section{The Image of the Çandarlı in the Anonymous Chronicles and Ahmedi}

We have already considered in brief how the Çandarlı are presented in the Anonymous Chronicles, and how certain institutions of the central state, such as the treasury, are attributed to their negative influence and that of other scholars (ulema). After Kafadar's general summary, which provides the main outlines, it is now time to take a more detailed look at some of these passages. The following is a close translation of one of the better-known extracts:

At that time [the reign of Murād I (1362-89)], tax [ harāc] was low. Things were such that even the infidels were not oppressed. They didn't take away their clothes and oxen, or their son and daughter, by making them sell them or give them as security [to pay their taxes]. At that time, the rulers [pädişählar] were not greedy; whatever came into their hands they gave away again, and they didn't know what a treasury was. But as soon as Hayreddin Paşa came to the gate of government, greedy scholars [dānişmend] became the companions of the rulers, and they gave up piety $[t a k v \bar{a}]$ in favor of the legal opinion $[$ fetv $\bar{a}]$. They said: "A treasury is a necessity for him who would call himself ruler". At that time, they turned the rulers to their side. It is said: "Greed and oppression have made their appearance. Naturally, where there is greed there will be oppression". Right now, it has become excessive. Whatever oppression and malice there is in these lands, it comes from the scholars. They are its cause. They realized that if they made use of their knowledge [ $[\mathrm{ilm}]$ then the entire population would submit to them. ${ }^{25}$

The anonymous source continues in the same vein, recounting a dialogue with a sufi holy man ( $b a b a)$ who blames corruption on members of the ulema. He goes on to point out how such corruption has increased in his own time (i.e. the late fifteenth century). Then comes the following passage:

25 Anonymous, ed. Giese, Die altosmanischen anonymen Chroniken, 25. My translation of this passage is a more literal version of that in Lewis, Islam, 135-136. 
In the times of Osmān, Orkhān Gāzī, and Murād, wine was not drunk. At that time there were ulema who made their words effective. At that time the Sultans were ashamed before the ulema and did not depart from whatever words they uttered. If in the house of Osmān any sin or injustice arose, they stopped it. Had they not stopped it, the ulema of that time would have left them, and none would have come to such a Pādishāh. The ulema of that time were not sinners like the ulema of today. They were men of standing who came to the gate of the Pādishāh... At that time, to fill the office of qạdīi, they used to seek a scholar from among the professors. A qadiship might remain vacant for a long time, and when a suitable scholar was found, he was not happy to accept appointment as qādīi. ${ }^{26}$

From the above lines, it becomes clear that there are serious problems with Wittek's stark distinction between frontiersmen and ulema. For here it is clear that what is at stake is not the value of the scholarly class per se, but the character of particular individuals belonging to it. Moreover, it is difficult to see in what way the discourse of decline in the above passages differs from that in the late sixteenth century Ottoman Empire, to say nothing of other times and places. ${ }^{27}$

So if not all ulema are to be blamed for the alleged corruption and decline of Ottoman society, whom in particular do the chronicles consider responsible for these problems? Once again, blame is placed squarely on the shoulders of Çandarlı Kara Halil. But he is not alone. Another scholar is also mentioned, who like Halil comes from the lands to the Ottomans' immediate east:

When the Persians and the Karamanlis became the companions of the princes of the house of Osmān, these princes committed all kinds of sins. Čandarlı Kara Halīl and the Karamanian Turk Rüstem were both at the time considered as great and learned. When these two came to the Ottoman princes, they filled the world with all kinds of cunning tricks. Until then nothing was known of keeping account books. When they came to the Ottoman princes, they compiled account books. The practice of accumulating money and storing it in a treasury comes from them. They

26 Anonymous, ed. Giese, Die altosmanischen anonymen Chroniken, 29-30; trans. Lewis, Islam, 138 .

27 On the Ottoman decline discourse, see Fleischer, Bureaucrat and Intellectual, 201-213; Kafadar, “The Question of Ottoman Decline”; Darling, A History of Social Justice, 139-148. 
had no thought of the end and did not remember that they would have to leave it all behind them, but were very proud of themselves. ${ }^{28}$

Apart from the above passage, nothing is known about "the Karamanian Turk Rüstem". However, his name suggests that he must have come from the principality of Karaman, the main Anatolian rival of the Ottomans into the late fifteenth century. We may also note here another key element of the chronicle's discourse: the idea that Kara Halil Çandarlı and Rüstem of Karaman were "both at the time considered as great and learned". If we consider this alongside other passages about ignorant qadis who cannot read and write, it is not difficult to see that contrary to Wittek's distinction between learned scholars and rustic raiders, what is really at stake here is the scholarly pedigree of the Çandarlı and their associates. ${ }^{29}$

The question of the scholarly qualifications of the Çandarlı and other influential early Ottoman scholars is a fruitful line of inquiry, which leads to another key source. This is the epic account of Ottoman history contained in Ahmedi's İskendernāme, a text generally thought of as the earliest extant, datable account of Ottoman history. ${ }^{30}$ In its final form, Ahmedi's İskendernāme dates from around 1410, and it has long been known that the section on Ottoman history is based on a lost prose chronicle. ${ }^{31}$ As a whole, the work is altogether more complex, and is best described as a long, didactic philosophical poem in which history holds a prominent place for its value in demonstrating the vanity of the pursuit of power without justice. Ahmedi's account of the Ottomans was written in the aftermath of their defeat by Timur in 1402 and contrasts their justice, piety, and zeal in the pursuit of religiously motivated warfare with the oppression of the Mongols who came before them. There is little doubt that descriptions of Mongol injustice are meant to evoke Timur; the work also contains references to the Byzantine-Ottoman conflict and other contemporary historical events. ${ }^{32}$

28 Anonymous, ed. Giese, Die altosmanischen anonymen Chroniken, 30; trans. Lewis, Islam, 139 .

29 For the passages about scholars in the time of Bayezid I and "in our own time" (i.e. the late fifteenth century CE) see Anonymous, ed. Giese, Die altosmanischen anonymen Chroniken, 29-32; Lewis, Islam, 138-141.

3o For a recent critical edition and translation of the Ottoman section, see Ahmedī, ed. Sılay, History of the Kings. For the entire work, the standard edition is Ahmedī, ed. Ünver, Iskender-näme. This is in fact a facsimile of a single manuscript with an introduction and table of contents.

31 Inalcık, "The Rise of Ottoman Historiography", 159-161.

32 For an analysis of this and other historical references in Ahmedi's İskendernāme, see Kastritsis, "The Alexander Romance". 
The fact that Ahmedi refers to several Ottoman rulers as holy raiders ( $\dot{g} \bar{a} z \bar{s} s)$ made his work ideal evidence for Wittek, who based his theory of the rise of the Ottoman Empire largely upon it. But there are many other aspects of the historical poem that have failed to attract the same attention. These include the following description of Çandarlı Kara Halil-Hayreddin:

When the Holy Raider Murād took his place (on the throne),

holy war and holy raid were his desire.

$\cdots$

Whoever came to him, whether poor or stranger,

would obtain a great share of his good fortune. ...

Leaving Çender on account of his poverty,

Halīl-i Çenderī appeared before him.

Despite the fact that his knowledge was little.

That in every grace, he was lacking and untoward,

[Murād] was understanding of his exile, sad condition, and poverty,

So graciously, he appointed him to high office.

In the end, he appointed him vizier over the dominion.

What vizierate? For he became a great prince. ${ }^{33}$

What are we to make of this description? First of all, it is worth noting that Ahmedi, possibly following his lost source, does not present an accurate account of Halil's background and career under the Ottomans. For while it is true that Kara Halil's rise to prominence coincided mostly with the reign of Murad I, who appointed him grand vizier, there is little to suggest that he was destitute before that time. Instead, Ahmedi's verses should be taken as a veiled critique of Halil's political influence, which the poet (or his lost source) seems to have considered out of proportion with his education. In other words, according to the poet, Halil's poverty was intellectual. Uzunçarşlı attributes this negative presentation to the fact that Ahmedi's own education was of a higher level, since he had studied in Cairo. ${ }^{34}$ However, as we have seen, this view is also consistent with his presentation in the Anonymous Chronicles, a source not generally known for its intellectual elitism. Should this common ground be

33 My translation is a more literal version of that in Ahmedī, ed. Sllay, History of the Kings, 11 . In the Ünver edition (Ahmedī, İskendernāme) this passage corresponds to verses $7672-7682$. However, not all verses are present in Ünver's manuscript. For the full text based on several manuscripts, see Aḥmedī, ed. Sılay, History of the Kings, 35-36 (verses 136-146). 
taken as a sign that Halil was indeed poorly educated? Not necessarily. But at the very least, we must accept that the question of scholarly qualifications and different educational backgrounds was one that was already being asked in early Ottoman society. This argument was apparently being used against the Çandarlı at the turn of the fifteenth century, if not earlier, by a court poet, whose sources (like those of the Anonymous Chronicles) were even older.

As indicated already, it is inadequate to speak of the Çandarlı family and its founder only in general terms. More detail is required if we are to approach the problem in its proper historical context. A brief account of key events will suffice for our purposes here. As we have seen, Ahmedi was writing around 1410, at a time when Ottoman society was struggling with the aftermath of a crushing defeat. In July of 1402, the first Ottoman attempt at empire had come to a sudden end on a battlefield near Ankara. When Timur withdrew from Anatolia the following spring, he left a territory devastated by the depredations of his nomadic army. The political landscape was highly fragmented, since Timur had reinstated as his clients several former beylik rulers, while also leaving Bayezid I's sons to fight for what was left of the Ottoman domains. This resulted in a period of civil war, during most of which the main contender for the Ottoman throne was Ahmedi's patron, Emir Süleyman (d. 1411). Süleyman's success was largely due to the fact that he had on his side a great part of the Ottoman ruling establishment. At the head of his administration was Kara Halil's son and successor to the office of grand vizier, Çandarl Ali Paşa. However, when Süleyman attempted to extend his power from the European side of the Ottoman domains to Anatolia, he faced a serious adversary in the person of his brother Mehmed (the future Mehmed I, r. 1413-21). This forced Süleyman to spend much of his reign in Anatolia, in an effort to expand and defend his power against Mehmed and other enemies. ${ }^{35}$

Such a policy was only possible thanks to the conclusion of a treaty with the Christian powers of the Balkans, which had involved territorial and other concessions. Çandarlı Ali Paşa played an important role in the peace negotiations leading to this treaty. However, he died in 1406, after Süleyman moved his base of operations to Anatolia. In the meantime, it seems that the marcher lords of Rumelia and other elements of Ottoman society based in Europe were becoming increasingly displeased with the treaty, because it hindered their raiding activity against Byzantium and other Christian lands. Their resentment eventually led to Süleyman's demise: various powers threatened by his rule (most notably his brother Mehmed) conspired to introduce yet another contender to 
the Ottoman throne. Presented with an alternative in the form of the young prince Musa, key members of Süleyman's administration deserted to Musa and assisted him in taking his brother's place. But in fact, after a mere two years, these same magnates began to desert Musa for Mehmed, who was thus able to take his brother's throne and reunify the Ottoman domains. One of the key deserters was another member of the Çandarlı family, Ali's brother İbrahim, the father of Murad II and Mehmed II's vizier Çandarlı Halil Paşa, who was executed in 1453 .

What bearing does all this have on Ahmedi's early fifteenth-century representation of Çandarlı Kara Halil? In fact, the above context is crucial to understanding his negative image, as well as that of the family as a whole. For regardless of when Ahmedi wrote the rest of his İskendernāme (and it is generally accepted that there were several drafts spanning decades), the section on Ottoman history was the last to be completed. In the aftermath of the 1402 debacle, and in light of the civil war pitting Süleyman against his brothers, it was essential to present the Ottomans as holy raiders conquering Christian land in the name of Islam. For that reason, Ahmedi criticizes Bayezid I's attacks against other Muslims. However, it was known to all that Süleyman had concluded a peace treaty with Byzantium and other Christian powers, which had been largely negotiated by Kara Halil's son Çandarlı Ali Paşa. His death in 1406, along with the rising threat of Süleyman's other magnates deserting to Musa, made it all the more important for Süleyman to distance himself from the Çandarlı and their past policies. It is in the context of this profound political crisis that we must interpret Ahmedi's verses. For after Ali Paşa's death in 1406, the Çandarlı were an easy target, just as they would be again after the execution of his nephew Halil in 1453. It seems Ahmedi was more than happy to oblige, since from his own perspective, the scholarly pedigree of the Çandarlı may already have been in question.

Some further evidence adds weight to this interpretation. For despite its unquestionable importance, the historical section of Ahmedi's Iskendernāme is neither the only account of Ottoman history produced in the early part of the fifteenth century, nor the only one from that time to cast the Çandarlı viziers in a negative light. Ahmedi's verses must be considered alongside the anonymous Aḥvāl-i Sulțān Mehemmed ('Tales of Sultan Mehmed').

The Aḥvāl-i Sulțān Mehemmed (hereafter Aḥval) is an epic account in prose completed during the reign of Mehmed I (1413-21), which has survived 
incorporated into two later chronicles. ${ }^{36}$ This text was apparently composed in the court of Mehmed I in order to aid him in his struggles against his brothers, and eventually justify his violent rise to the throne. While it is impossible to be certain of its date of composition, its contents and structure suggest that it was written gradually as events were taking place, probably receiving its final form between 1413 and 1416. It is a lively work of epic prose, whose representation of its hero, Sultan Mehmed I, is reminiscent of the Persian epic Book of Kings (Firdawsi's Shahnäma). The work has only one true hero, the conquering sultan, but several villains including the grand vizier Çandarlı Ali Paşa. As we have seen, Ali was a suitable target because he was serving Mehmed's brother and rival, Emir Süleyman. His role in the narrative is therefore connected to Süleyman's activity in Anatolia, where he and Mehmed competed for the Ottoman territory that remained after Timur's departure. It is worth taking a detailed look at the presentation of Ali Paşa in the Ahqvāl. For as we will see, this shares some common elements with his more explicit vilification in the Anonymous Chronicles.

In the $A h q u \bar{l} l$, there are two key occasions on which Ali Paşa commits treachery against Mehmed. Each involves military confrontation between the Ottoman prince and his brother Süleyman, in which Mehmed would have gained the upper hand were it not for the deception of Ali Paşa. On the first of these, Ankara is under siege by Süleyman's far superior army. Afraid of falling into his brother's hands, Mehmed abandons the city and returns to his own base in the province of Rum (here defined as the region around Amasya and Tokat). He leaves the defense of Ankara in the hands of its governor, a man named Yakub Bey whose family played a prominent role in early Ottoman history. ${ }^{37}$ However, its inhabitants open the gates to Süleyman, and Yakub has no choice but to take refuge in the citadel. Eventually he becomes desperate and sends messengers to Mehmed requesting assistance. When they reach Mehmed, he instructs his chancery to compose a letter of reply to Yakub, informing him that he is prepared to come to his assistance if he can only hold out a few more days. His reply is sent back with the messengers who had brought the original letter. However, on their way back they are captured by Süleyman's forces. As a result,

36 On this work and its significance, see Kastritsis, "The Historical Epic"; Kastritsis, The Sons of Bayezid, 28-33, 206-216. For a full English translation, see Kastritsis, The Tales of Sultan Mehmed. I published an improved, annotated translation based on the most important manuscript in Anonymous, An Early Ottoman History: The Oxford Anonymous Chronicle (pp. 97-151).

37 His father had also been governor, and he was an ancestor of Tursun Bey, the chronicler of Mehmed the Conqueror. See Kastritsis, The Sons of Bayezid, 115. 
Yakub's letter to Mehmed ends up in the hands of Ali Paşa, who replaces it with a forgery. Here is how the $A \not h v \bar{a} l$ presents this key moment in the narrative:

Bulgur Ağa took the letter and set out to deliver it, but was captured along the way. He was brought to Ali Paşa, who questioned him and was able to obtain full knowledge of the letter's contents. [Ali] perpetrated a kind of deception, retaining the sultan's letter and replacing it with one written by himself. This was addressed to Yakub Bey as if from the sultan's mouth, and was sent back [with the same messenger]. It read, 'Yakub Bey! Now you have sent a letter informing me of the citadel's situation. This being the case, do not request assistance from me, for I am unable to reach you there. You have done well to make such a valiant effort to defend the citadel in my name. However, since matters have taken such a turn, you are to cease all fighting and surrender the castle to my older brother'. Perpetrating such a deception, Ali Paşa sent the letter to Yakub Bey. By the time it reached him, he had become most desperate. What could he do? Acting out of ignorance, he opened the gate and came out, kissed Emir Süleyman's hand, and surrendered the citadel to him. ${ }^{38}$

What is most striking about this extract is that the negative presentation of Ali Paşa, while certainly present, is much less explicit than in the relevant passages of the Anonymous Chronicles. This makes sense, since the later passages also reflect the perspective of a time when the Çandarlı family had been disgraced following the conquest of Constantinople. When the above passage from the $A h v a \bar{l}$ was written (ca. 1413), the family was still influential. It is true that Ali Paşa was an enemy of the Ahval's protagonist and patron, Mehmed I, because he had served his brother and rival. However, around 1411, Ali Paşa's brother İbrahim actually joined Mehmed's court. ${ }^{39}$ But in fact, there is a good chance that the passage we have just seen was written between 1406 and 1411, when there were as yet no members of the family on Mehmed's side.

In any case, what is of greatest interest here is not the negative presentation per se, but the form that it takes. We can gain further insight into the nature of the critique by examining another passage. This comes later in the narrative, but still in the context of Mehmed and Süleyman's power struggle in Anatolia. After losing Ankara to his brother, Mehmed withdraws to his base in AmasyaTokat. But he does not give up, and is always looking for an opportunity to

38 Oxford Anonymous (Bodleian Marsh 313), 81v-82r. My updated translation. See also Kastritsis, The Tales of Sultan Mehmed, 25-26, 70-71 (original text).

39

Kastritsis, The Sons of Bayezid, 165-166. 
confront Süleyman and regain the upper hand. While he is feasting with the people of his court, a messenger enters with the following message:

O Shah of the World! Some time ago you had sent your servant to Bursa. I went there and carried out a complete investigation. Your brother is practically alone, having only six hundred men by his side. He is occupied with drinking day and night, to such an extent that when he enters the bath to drink wine, he spends an entire month there feasting and enjoying himself. Such an opportunity presents itself but rarely. If you wish to attack, this is a most opportune moment. ${ }^{40}$

The story is a lengthy one, but may be summarized as follows. Mehmed becomes excited at the opportunity presented to confront his brother Süleyman. Seizing the day, he sets out with his army in the direction of Bursa. He eventually reaches the Sakarya river, where he encounters one of Süleyman's officials, who has come to carry out a tax survey of the province. ${ }^{41}$ The official asks Mehmed's men who they are; they reply, "You'll see who we are!" and chase him away. He hastens back to Süleyman, who is thus informed of Mehmed's imminent arrival. Süleyman panics, throws down his wine goblet, and declares that the only course of action is to escape to the safety of Rumelia, on the European side of the straits. But Ali Paşa reassures him by suggesting a different plan. He reminds him that since he is in possession of the land, it is possible to hold out until Mehmed is forced to leave. He suggests an inaccessible place near Yenişehir, adding that if Mehmed is somehow able to gain the upper hand, Ali will write a letter convincing him to depart without delay. Events play out exactly as predicted. Mehmed and his army persevere, despite difficult terrain and inclement weather, and Ali Paşa resorts once again to his epistolary skills and his talent for deceit. He writes a letter to Mehmed, informing him of treason in his ranks. Mehmed does not believe the letter and continues to fight, but the seeds of doubt have been sowed in his mind. When one of Mehmed's cupbearers deserts to the enemy (perhaps unable to resist the temptation of employment at Süleyman's court), Mehmed takes the event as a sign that Ali Paşa was right. He abandons the struggle, and Süleyman's throne is saved. ${ }^{42}$

In the above story, we may discern several key elements. These include Mehmed's bravery; Süleyman's cowardice and love of luxury; and finally,

40 Oxford Anonymous, 82v-83r; Kastritsis, The Tales of Sultan Mehmed, 26, 71.

41 ilyazmaġa... gelmişdi. Oxford Anonymous, 83r; Kastritsis, The Tales of Sultan Mehmed, 26, 72 .

42 Oxford Anonymous, 83r-85r; Kastritsis, The Tales of Sultan Mehmed, 27-28, 72-73. 
Çandarlı Ali Paşa's cunning and reliance on the written word. The mention of a land survey is especially intriguing, as it would probably have had special connotations for the Ahvāl's audience. Like other elements in the narrative, such references to Ottoman bureaucratic practices for which as we have seen the Çandarlı were held responsible may be regarded as a precursor to the much more explicit critique of the Anonymous Chronicles. However, as we saw in Kafadar's survey, another key discursive element in the Chronicles concerns the practice of courtly drinking parties. This, too, is present in the $A h v \bar{a} l$, as well as in several other sources from the early fifteenth century. Specifically, what is critiqued in these narratives is the prince Süleyman's love of wine and courtly entertainment. This constitutes another element deserving our attention, for it is directly related to the discourse about the Çandarlı and centralization. It is to this point that we will now turn.

If there is any doubt that stories about Süleyman's drinking were circulating around the time of his death in 1411, this may be easily dispelled by the following laconic entry in a Byzantine short chronicle:

As Emir Sülman had taken to bathing and was drinking one glass after another, the lords and grandees got fed up, and the armies left and began to desert to Musa Bey. When Emir Sülman heard this, he was afraid and tried to escape. But he was caught in the area of Bryse and strangled, on February 17 which was a Tuesday. ${ }^{43}$

We have seen that in the Anonymous Chronicles, a literary tradition that in its present form dates to the end of the fifteenth century, the topos of royal drinking appears as one of many negative elements, alongside the corruption of the Çandarlı viziers and other members of the scholarly classes. The fact that many of these elements are already present in the early part of that century, many years before the centralizing reforms of Mehmed II, demands an explanation. If such stories were indeed a reaction against increased royal power and centralization, this reaction was already present in the aftermath of 1402 , when the first Ottoman attempt at empire collapsed and those opposed to it must have felt vindicated. In the ensuing dynastic war, first Mehmed and then Musa took

43 Schreiner, Die byzantinischen Kleinchroniken, vol. 1, 637. My translation. For further commentary on this passage, see Kastritsis, The Sons of Bayezid, 154-155. 
advantage of the fact that their successful older brother Süleyman had come to be associated with their late father Bayezid's defeated regime, with its supposed emphasis on court culture and centralization.

Süleyman's association with Bayezid's regime seems to have had several aspects. As we have seen, one of these was that he was served by Çandarlı Ali Paşa and other key members of Bayezid's administration. Another was his close relationship with the Christian elites of Rumelia and the Aegean region. It is true that this relationship was essentially different, since Bayezid was able to follow an aggressive policy toward the Christian world, whereas Süleyman was forced to surrender important Ottoman possessions to Byzantium and other powers in exchange for peace. Such important policy differences notwithstanding, however, the fact remains that both had extensive dealings with Christians. It was precisely in this area that the Çandarlı family's role appears to have been indispensable. We have already seen that the last important member of the family, Çandarlı Halil Paşa, was executed following the conquest of Constantinople, because he was seen as a collaborator with the infidel ( $g \bar{a} v u r$ ortağı). This characterization is generally thought to have stemmed from the fact that he was opposed to prolonging the siege of the city, favoring instead a more accommodating stance toward Byzantium. But in fact, these accusations appear to have had deeper roots. ${ }^{44}$

To better elucidate the matter, we may now turn to another source, the late fifteenth-century chronicle of 'Āşıkpaşazāde:

Emir Süleyman sent an ambassador to Karamanoğlu and Germiyanoğlu with the message, "Do not release my brother Musa, and I will be most friendly toward you". When Musa found out that his brother had made peace with Karamanoğlu, he escaped to İsfendiyar. Emir Süleyman was in Bursa. He heard that Musa had gone to İsfendiyar and marched on him until he reached Göynük, where he camped on the banks of a river. At that time it was summer. When winter came he wintered there, never leaving that location. It became known thereafter as "the bey's poplar", because Emir Süleyman was always conversing and making merry there under a poplar tree. Then Süleyman made peace with İsfendiyar, so he left that place and reached İznik. There he occupied himself once again

44 It is worth pointing out the parallels (and possible connections) between the Çandarlı before 1453 and the Notaras family in Byzantium at the same time. See Angold, The Fall of Constantinople, 8-9, 34-36; Necipoğlu, Byzantium between the Ottomans and the Latins, 214-218. 
with merrymaking, drinking Ali Paşa's free wine. İsfendiyar put Musa in a ship at Sinop and sent him to Wallachia. ${ }^{45}$

There is no need to dwell here in detail on the political events to which the passage refers. These were highly complex, and were related to the power struggle in Anatolia between the Ottoman princes Mehmed and Emir Süleyman, which drew in many neighboring powers, including the ruler of Sinop, the İsfendiyar mentioned in the text. ${ }^{46}$ Suffice it to say, the key event that ended the stalemate between the two brothers was the Black Sea crossing of a third prince, their brother Musa. In reality, this was the outcome of a coordinated effort by Süleyman's many enemies to undermine his rule by invading his European territory from the north. Intriguingly, however, in some manuscripts of the Anonymous Chronicles, there is another version of the above passage, which places responsibility for this cunning scheme squarely on the shoulders of Ali Paşa:

In the end, [Süleyman] made peace with İsfendiyar. Then he left and went to İznik. There he occupied himself once again with merrymaking. Seeing that he never stayed away from wine, all the people were offended by his bad habit. With the intercession of Ali Paşa, İsfendiyar put Musa in a ship at Sinop and sent him to Wallachia. ${ }^{47}$

It is worth digressing for a moment to consider this difference between 'Āşıppaşazāde and this version of the Anonymous Chronicles. As is usually the case, the texts in question are based on a common source, so discrepancies may be due at least in part to textual transmission. Even if this is the case, this passage deserves our attention: for the idea that Ali Paşa could have been behind Musa's Black Sea crossing is absurd, and shows the extent of the Çandarlı's demonization. For Ali Paşa (d. 1406) was Süleyman's vizier, and was almost certainly dead at the time of Musa's Black Sea crossing. ${ }^{48}$

Such inconsistencies would have been obvious to 'Āşıkpaşazāde, who had lived through some of the events in question. In his chronicle, as in the Ahqvāl, emphasis is placed instead on Süleyman's courtly drinking habits. But there is a salient detail here that deserves further scrutiny: this is the reference to "Ali Paşa's free wine" ('Alī Paşa'niñ müft şarābı). As we saw earlier, in the Anonymous

45 'Āşılkpaşazāde, ed. Giese, Tevārāhh-i Āl-i 'Oșmān, 73.

46 On these events and alliances, see Kastritsis, The Sons of Bayezid, 129-134.

47 Anonymous, ed. Giese, Die altosmanischen anonymen Chroniken, 48 (text), 132 (apparatus).

48 Kastritsis, The Sons of Bayezid, 135-136. 
Chronicles as summarized by Kafadar it is a Serbian princess who is blamed for introducing wine drinking to the Ottoman court. This is said to have happened during the reign of Süleyman's father Bayezid, when the princess in question became his concubine following the Serbian defeat at Kosovo (1389). Needless to say, there is nothing striking about a Christian princess being blamed for introducing wine-drinking into a Muslim court. But the mention of Ali Paşa, and specifically the expression "free wine", is an intriguing element that needs to be explained.

In fact, such explanation comes from a surprising quarter: the expense accounts of the Genoese colony of Pera. There we may find the following brief entries:

1403, 26 June. Present made to his lordship Mosormano Jhalabi [i.e. Emir Süleyman Çelebi], who is dominant in Greece ... for which we are owed ... and it is for 8 jars, purchased from the same person to be filled with wine for them ... Likewise, 27 June ... for Malvasia wine ... Likewise, 8 July, to Francisco de Canicia. And it is for 4 jars, in which was placed wine to be given as a gift to Ali Paşa and Balaban, who are barons of the aforementioned Jhalabi [i.e. Süleyman] ... Likewise, 28 June ... for Malvasia, 1 metron, presented and gifted to a certain Turk, who is the brother of Ali Paşa ... hyperpyra 2, keratia 3 ... 1403, 27 July. Present made to his lordship the Emperor Calojani Paleologo [John VII], etc. ... for Malvasia ... 1403, 10 July. Present made to his lordship Balaban, lord of Greece and general, etc. ... for Malvasia wine, 2 metra, purchased from a certain tavern-keeper for the aforementioned lord Balaban. ${ }^{49}$

One question that immediately arises concerns the identity of the man named Balaban. This name is common in early Ottoman history, and is associated with several early Ottoman magnates, so it is impossible to identify its bearer with complete certainty. However, one individual is by far the likeliest candidate: a protégé of Ali Paşa, one of three converts to Islam whose names appear as witnesses on the foundation document (vakfiyye, Ar. waqfiyya) of his foundation in Bursa. The document is dated 1405, as is another apparently issued by the same Balaban, which is preserved in a monastic archive. ${ }^{50}$ If it is indeed the case that the Genoese accounts and the two Ottoman documents refer to the same person, then it makes sense to speak of someone belonging to Çandarlı

49 Iorga, Notes et extraits (ROL), 86-88.

50 Kotzageorgis, "An Ottoman Document", 263. See also Uzunçarşıll, Çandarlı Vezir Ailesi, 45; Uzunçarşıll, "Çandarlı-zade Ali Paşa Vakfiyesi", 558, 562. 
Ali's inner circle. In fact, there is a strong likelihood that Balaban was a manumitted Christian captive who had converted to Islam. Needless to say, this is all somewhat speculative; but the Genoese accounts leave little doubt that Balaban and Ali were close associates, and were involved in procuring gifts of wine for the Ottoman prince Süleyman.

It is also worth noting the mention of Ali Paşa's brother. There can be little doubt that the man in question is Çandarl İbrahim, the father of the Halil Paşa executed in 1453. Although İbrahim played an important role in this period of Ottoman history, he has escaped the negative presentation accorded to his relatives in the chronicles. His more positive image appears to have been due to the twin facts that he was less powerful than his brother, and that he eventually ended up in Mehmed I's camp. ${ }^{51}$ The fact that his defection took place via Constantinople suggests that he shared his family's diplomatic links to the Byzantine capital and its Genoese sister settlement, as demonstrated also by his presence in the above expense accounts.

The mention of Ottoman dignitaries in the Genoese accounts is highly significant, for it sheds light on what appear in the Ottoman narratives to be little more than exaggerated stories designed to denigrate these people. It is striking to see some of them described in the Genoese records in similar terms as the Byzantine Emperor, notably as recipients of generous quantities of Malvasia wine. Of course, wine was not the only gift they received. Luxury textiles are also mentioned, as are expenses related to an elephant and some court jesters. But if anything, such gifts further confirm Süleyman's presentation in Ottoman sources as a lover of courtly luxuries. It is clear that at least part of the time, these goods were also procured by the Çandarlı family and their dependents; and not everyone would have been sympathetic to the idea that they were necessary trappings of an established Islamic ruler.

Finally, what should we make of the fact that Süleyman and his magnates seem indeed to have indulged in the consumption of wine? First of all, there is little doubt that this was far from uncommon in the Muslim courts of medieval Anatolia. In fact, devotees of the beverage apparently included even the great $\dot{g} \bar{a} z \bar{l}$ leader Umur of Aydın. ${ }^{52}$ However, what seems to have been of key importance was the precise setting and mode of its consumption. In the anonymous Ahval, following a common Persian convention, each chapter ends with the hero, Süleyman's brother Mehmed, holding banquets and drinking parties with his men. Such feasting conforms to an epic mode that evokes the kings

$5^{1} \quad$ On İbrahim's defection to Mehmed, see Kastritsis, The Sons of Bayezid, 165-166.

$5^{2}$ For some examples of wine-drinking involving Muslim rulers of Anatolia, see Fleet, European and Islamic Trade, 74 . 
and other heroes of the Shāhnāma, and is therefore fundamentally different in nature from the same source's presentation of Süleyman. Mehmed's feasting is a suitable manly complement to hard-fought battles, which may be summarized with the common Persian expression bazm u razm ('banquet and battle'). In contrast, Süleyman's drinking takes place in the bath, while surrounded by poets and other courtiers, deaf to his generals' calls for military action. It is for this reason that he is ultimately unfit to occupy the throne. ${ }^{53}$

The above analysis allows us to arrive at several tentative conclusions. The first concerns the development over time of a coherent political discourse opposed to the creation of a strong Ottoman central state. We have seen that a kernel of that discourse was already present in the early fifteenth century, but had not yet developed into what we might call the classic formulation of the Anonymous Chronicles. By the late fifteenth century, when these chronicles were compiled, it was possible to blame the development of Ottoman society over more than a century on several generations of the Çandarl family, together with other people and groups. By then, generalizations could be made about "men of knowledge" (dānişmend) as a social category, which could be blamed retrospectively for "whatever oppression and corruption there is in this land". It is precisely this discourse that was seized upon by Wittek and his followers, who read into it a neat distinction between $\dot{g} \bar{a} z \bar{\imath} s$ and ulema. But in the early part of the fifteenth century, such social divisions were not yet as clear.

As we have seen, there can be little doubt that stories about Çandarlı Ali Paşa and his father, Kara Halil-Hayreddin, were already circulating in the years around 1402. This is hardly surprising, considering the strong role of the family in the first Ottoman attempt at empire under Bayezid I. It is undoubtedly the case that their close connection to power had created resentment, not least because the centralization and institutionalization with which they were involved had alienated social groups with vested interests. In this respect, the late fourteenth century CE was not unlike the late fifteenth, when Mehmed II made his unpopular centralizing reforms. But unlike Mehmed II's highly successful imperial venture, the failure of the first Ottoman attempt at empire was taken by some as proof that those behind it were misguided, even guilty of a

53 For the different accounts of Süleyman's loss of power, see Kastritsis, The Sons of Bayezid, 153-158. For the relevant section of the Ahväl, see Oxford Anonymous, 89v-91v; Kastritsis, The Tales of Sultan Mehmed, 31-32, 77-78. 
direct offense against God. For the Timurid debacle of 1402 had created a situation in which it was easy to draw connections between several trends that had been on the rise in the preceding years. These included the introduction of taxation, slave soldiers, and other centralizing institutions; aggressive policies toward other Muslim states, which relied largely on the aforementioned slave soldiers as well as armies provided by Christian clients; a rise in diplomatic activity, often involving Christian powers, in which it was standard practice to exchange gifts of wine and other luxury goods to be consumed in a courtly setting; and the rise of the Ottoman court itself, which was now in a position to attract such important poets and intellectuals as Ahmedi.

These developments are closely mirrored in the careers of the first two Çandarlı viziers. After 1402, like other high-ranking members of Bayezid's administration, Ali Paşa had supported Bayezid I's son Emir Süleyman. In the immediate aftermath of Timur's victory, Süleyman and his court were forced to abandon Anatolia, then make peace with Byzantium and other Christian powers in exchange for security. In so doing, they alienated various social groups, especially the raiders and others relying for their livelihood on aggression against the Christian world. Although many of the grievances that surfaced in 1402 seem to have had roots in the policies of Murad I and Bayezid I, neither of these rulers could be accused of taking a conciliatory stance toward Christendom. But after the Ottoman defeat, their heirs were in the unenviable position of trying to reunite what was left under the pressure of numerous threats, the greatest of which was another Timurid intervention. Although peace with the Christian world gave Süleyman and Ali Paşa an opportunity to turn their attention toward Anatolia, this came at an enormous cost. For just as Süleyman had a competent advisor in the person of Ali Paşa and a court panegyrist in the poet Ahmedi, his brother and rival Mehmed had his own advisor, his very competent tutor Bayezid Paşa, and literati of his own. ${ }^{54}$ Probably under the direction of Bayezid Paşa, Mehmed's court was able to exploit popular discontent and the culture of epic poetry and storytelling in the service of his political agenda. For how else to explain the fact that rumors of events such as Ali Paşa's diplomatic exploits and Emir Süleyman's courtly wine-drinking found their way into the anonymous $A \not h v \bar{a} l$, in addition to other historical narratives?

The most important lesson to be learned is that when considering social divisions in early Ottoman society as represented in literary sources, it is not enough to think in terms of such simple categories as frontiersmen versus ulema, or even centralization and its discontents. It is also necessary to consider the role of rumors, propaganda, and the popularity of epic storytelling in 
the period in question. For how could stories we have come to associate with a coherent Ottoman discourse against centralization also appear in "official" propaganda narratives from an Ottoman court, as well as Christian sources? Crucially, this is not simply a matter of accepting that the stories in question must therefore be true. While they may indeed have been based on true events, they were also circulating as rumors that could cross the boundaries of language. Such stories had a life of their own, but could also be manipulated for political purposes. In light of the above considerations, it is not unreasonable to suggest that what might appear by the late fifteenth century to be the voice of the $\dot{g} \bar{a} z \bar{s}$ opposed to Mehmed II's centralization reforms can be traced at least in part to the court of his grandfather and namesake, Mehmed I.

Perhaps the best illustration of the importance of context and storytelling is the following passage from the Greek chronicle of Chalkokondyles (ca. 146os). Like many of the Ottoman ones we have considered, its protagonist is Çandarlı Kara Halil/Hayreddin:

Hayreddin took over Thessalonike and enslaved the rebels. He was held in high esteem by Murad, although previously too he had risen high in his service and wielded great power. Many worthwhile stories are told about Hayreddin, about how he would advise Murad on what needed to be done and accomplished great deeds in both Asia and Europe while serving him in most matters. Some of his sayings to Murad in discussions of judgment and strategy are recorded. It is thus said that he once asked, "O Sultan Murad, how should one best conduct a campaign so as to most easily accomplish one's goals?" It is reported that Murad answered, "By planning well and treating the soldiers as well as possible". Hayreddin asked again, "And how do you plan properly?" He said, "If you use the right calculations and do not make mistakes in them". At this point it is said that Hayreddin laughed loudly and said to him, "O Sultan Murad, you might seem to be most wise. But how could one make these calculations without being present to actually observe both what needs to be done and its opposite, and thereby avoid the latter while choosing to pursue the former, and so achieve what is necessary?" In this way he hinted that it was speed that accomplished great deeds, more so than other good qualities, and that there is nothing that a general should practice more than speed and swift application, and that he should be everywhere that he has to be. Conversing about such matters with each other, they showed that they did not lack judgment about what was required. ${ }^{55}$ 
In certain respects, this story bears a remarkable resemblance to some of those in the Anonymous Chronicles. Without its original context, however, it ultimately makes little sense. As pointed out by the passage's translator, Anthony Kaldellis, this is one of many cases where Chalkokondyles is relying on Ottoman sources, which were probably communicated orally. ${ }^{56}$ Indeed, the chronicler states as much when he tells us that "many worthwhile stories are told about Hayreddin". However, in the words of Kaldellis, here "the Turkish original only haunts the text" since "it is no longer alive". ${ }^{57}$ In order to understand this and other stories, it is necessary to study them side by side in the context of political events and social circumstances. This is a project begun by Paul Wittek, but only in the broadest, most impressionistic terms, and under the influence of a romantic view of history. Today, however, the time is ripe for a more detailed, careful, and comprehensive examination, one which should transcend the arbitrary boundaries of language, period, and genre.

\section{Bibliography}

\section{Primary Sources}

'Abdülvasī Çelebi, Halīlnāme, Ayhan Güldaş, ed. (Ankara, 1996).

Ahmedī, History of the Kings of the Ottoman Lineage and Their Holy Raids Against the Infidels, Kemal Silay, ed. and trans. [Sources of Oriental Languages and Literatures, vol. 64] (Cambridge, Mass., 2004).

Aḥmedī, İskender-nāme: İnceleme, Tipkıbasım, İsmail Ünver, ed. (Ankara, 1983).

Anonymous, Die altosmanischen anonymen Chroniken, Friedrich Giese, ed. (Breslau, 1922).

Anonymous, An Early Ottoman History. The Oxford Anonymous Chronicle (Bodleian Library, Ms Marsh 313). Historical Introduction, translation, and commentary by Dimitri J. Kastritsis [Translated Texts for Byzantinists, vol. 5] (Liverpool, 2017).

Anonymous, The Tales of Sultan Mehmed, Son of Bayezid Khan: Annotated English Translation, Turkish Edition, and Facsimiles, Dimitri Kastritsis, trans. \& ed. [Sources of Oriental Languages and Literatures, vol. 78] (Cambridge, Mass., 2007).

'Āşıkpaşazāde, Tevārĭhh-i Āl-i 'Oșmānn, Friedrich Giese, ed., Die altomanische Chronik des Āšskpašazāde auf Grund mehrerer neuentdeckter Handschriften (Leipzig, 1929).

Chalkokondyles, Laonikos, The Histories, Anthony Kaldellis, trans., 2 vols. (Cambridge, Mass, 2014).

$5^{6}$ Kaldellis, A New Herodotos, 126-147. On Laonikos Chalkokondyles and his sources, see also Akışık, "Self and Other in the Renaissance".

57 Kaldellis, A New Herodotos, 140. 
Lewis, Bernard, ed., Islam from the Prophet Muhammad to the Capture of Constantinople. (New York, 1974).

\section{Secondary Sources}

Akışı, Aslıhan, "Self and Other in the Renaissance: Laonikos Chalkokondyles and Late Byzantine Intellectuals" (unpublished Ph.D. thesis, Harvard University, 2013).

Angold, Michael, The Fall of Constantinople to the Ottomans (Harlow, 2012).

Ayverdi, Ekrem Hakkı, Osmanli Mímârîsinin İlk Devri: 630-805 (1230-1402) (İstanbul, 1966).

Babinger, Franz, Mehmed the Conqueror and His Time (Princeton, 1978).

Balta, Evangelia, Les vakifs de Serrès et de sa région (XVe et XVIe s.): un premier inventaire (Athens, 1995).

Barkey, Karen, Bandits and Bureaucrats: The Ottoman Route to State Centralization (Ithaca, 1994).

Darling, Linda, "Introduction: Ottoman Identity and the Development of an Ottoman Imperial Culture in the Fifteenth Century",Journal of the Ottoman and Turkish Studies Association 1 (2014): 53-55.

Darling, Linda, A History of Social Justice and Political Power in the Middle East: The Circle of Justice from Mesopotamia to Globalization (New York, 2013).

Fleet, Kate, European and Islamic Trade in the Early Ottoman State: The Merchants of Genoa and Turkey. (Cambridge and New York, 1999).

Fleischer, Cornell H., Bureaucrat and Intellectual in the Ottoman Empire: The Historian Mustafa Âli (1541-160o) (Princeton, 1986).

Imber, Colin, The Ottoman Empire 1300-1481 (Istanbul, 1990).

İnalcık, Halil, Fatih Devri Üzerinde Tetkikler ve Vesikalar (Ankara, 1954).

İnalcık, Halil, “Ottoman Methods of Conquest”, Studia Islamica 2 (1954): 103-129.

İnalcık, Halil, "The Rise of Ottoman Historiography", in Bernard Lewis and P.M. Holt, eds., Historians of the Middle East (London, 1962), pp. 152-167.

İnalcık, Halil, The Ottoman Empire; the Classical Age, 1300-16oo (New York, 1973).

İnalcık, Halil, "Centralization and Decentralization in Ottoman Administration", in Thomas Naff and Roger Owen, eds., Studies in Eighteenth Century Islamic History (Carbondale, 1977), pp. 27-52.

İnalcık, Halil, "Impact of the Annales School on Ottoman Studies and New Findings", Review (Fernand Braudel Center) 1, no. 3/4 (1978): 69-99.

İnalcık, Halil, An Economic and Social History of the Ottoman Empire. Volume One: 13001600 (Cambridge, 1994).

Iorga, Nicolae, "Notes et extraits pour servir à l'histoire des croisades au xve siècle", Revue de l'Orient Latin 4 (1896): 25-118, 226-320, 503-622.

Kafadar, Cemal. Between Two Worlds: The Construction of the Ottoman State (Berkeley, 1995). 
Kafadar, Cemal, "The Question of Ottoman Decline", Harvard Middle Eastern and Islamic Review 4, no. 1 (1998): 30-75.

Kaldellis, Anthony, A New Herodotos: Laonikos Chalkokondyles on the Ottoman Empire, the Fall of Byzantium, and the Emergence of the West (Cambridge, Mass., 2014).

Kastritsis, Dimitris J., The Sons of Bayezid: Empire Building and Representation in the Ottoman Civil War of 1402-1413 [The Ottoman Empire and Its Heritage, vol. 38] (Leiden and Boston, 2007).

Kastritsis, Dimitris J., The Tales of Sultan Mehmed, Son of Bayezid Khan. Annotated English Translation, Turkish Edition, and Facsimiles (Cambridge, Mass., 2007).

Kastritsis, Dimitris J., “Ottoman Anonymous Chronicles”, in R.G. Dunphy, ed., Encyclopedia of the Medieval Chronicle (Leiden and Boston, 2010), 1177-1178.

Kastritsis, Dimitris J., "The Historical Epic Ahvvāl-i Sultān Mehemmed (The Tales of Sul$\tan$ Mehmed) in the Context of Early Ottoman Historiography", in E. Çıpa and E. Fetvacl, eds., Writing History at the Ottoman Court: Editing the Past, Fashioning the Future (Bloomington, 2013), 1-22.

Kastritsis, Dimitris J., "Bāyezīd Pasha (d. 1421)", The Encyclopaedia of Islam, Three (2015).

Kastritsis, Dimitris J., "The Alexander Romance and the Rise of the Ottoman Empire", in A.C.S. Peacock and S.N. Yıldız, eds., Literature and Intellectual Life in Fourteenthand Fifteenth-century Anatolia, ed. (Würzburg, 2016), 243-283.

Kotzageorgis, Phokion P. "An Ottoman Document from 1405 and Its Problems", Turcica 46 (2015): 257-278.

Lowry, Heath W., The Nature of the Early Ottoman State, (Albany: State University of New York Press, 2003).

Necipoğlu, Nevra, Byzantium between the Ottomans and the Latins: Politics and Society in the Late Empire (Cambridge and New York, 2009).

Murphey, Rhoads, "Bayezid I's Foreign Policy Plans and Priorities: Power Relations, Statecraft, Military Conditions and Diplomatic Practice in Anatolia and the Balkans", in Nikolaos G. Chrissis and Mike Carr, eds., Contact and Conflict in Frankish Greece and the Aegean, 1204-1453 (Farnham, Surrey, and Burlington, VT, 2014), 177-215.

Schreiner, Peter, Die byzantinischen Kleinchroniken [Corpus Fontium Historiae Byzantinae, vol. 12], 2 vols. (Vienna, 1975).

Taeschner, Franz, and Paul Wittek, "Die Vezirfamilie der Ğandarlyzāde (14./15. Jhdt.) und ihre Denkmäler", Der Islam 18 (1929): 58-115.

Uzunçarşılı, İsmail Hakkı. Çandarli Vezir Ailesi (Ankara, 1974).

Uzunçarşıll, İsmail Hakkı. "Çandarlı Zâde Ali Paşa Vakfiyesi". Belleten (Türk Tarih Kurumu) 5, no. 20 (1941): 549-576.

Wittek, Paul, "De la défaite d'Ankara à la prise de Constantinople", Revue des études islamiques 12 (1938): 1-34. 
Wittek, Paul, The Rise of the Ottoman Empire: Studies in the History of Turkey, ThirteenthFifteenth Centuries, Colin Heywood, ed. (Milton Park, Abingdon, and New York, 2012).

Wittek, Paul, The Rise of the Ottoman Empire [Royal Asiatic Society Monographs, vol. 23] (London, 1938).

Yürekli, Zeynep, Architecture and Hagiography in the Ottoman Empire: The Politics of Bektashi Shrines in the Classical Age [Birmingham Byzantine and Ottoman Studies 12] (Farnham, Surrey and Burlington, VT, 2012). 